\title{
THE USE OF GENERATING INTERACTION BETWEEN SCHEMATA AND TEXT (GIST) STRATEGY TOWARDS STUDENTS' READING COMPREHENSION
}

\author{
Venny Octavia $^{1}$, Eka Wilany $^{2}$ \\ English Department, Teacher Training and Education Faculty, University of Riau Kepulauan, Batam, Indonesia \\ Email:vennyoctavia22@gmail.com ${ }^{1}$, ekawilany3@gmail.com ${ }^{2}$
}

\begin{abstract}
As a foreign language learner, Indonesian students are not easy to comprehend the text in English; the students have to understand implicit and explicit meaning in the text. It is also not easy for them to get the implicit meaning in interpreting the meaning and purpose of an English text. Strategy in teaching English specifically reading comprehension can affect the student achievement in learning. One of the teaching strategies that is considered useful is Generating Interaction between Schemata and Text (GIST) strategy that provides an opportunity for students to identify important vocabulary and synthesize important pieces of information into summary statement to show the gist of the reading. The research was conducted by using experimental design in quantitative approach. It was conducted to know whether there was any significant effect of Generating Interaction between Schemata and Text (GIST) strategy toward students' reading comprehension. The instrument used to assess the students reading comprehension was reading test that distributed to the students in the experimental and control class. The sample of the research was 73 students, from 2 classes. The hypotheses was calculated by using t-test in which the analysis result obtained $t_{\text {count }}=7.63>t_{\text {table }}=1.99$ with $\alpha=0,05, d k=n 1+n 2$ $2(37+35-2)=70$. It means that there was significant effect of GIST Generating Interaction between Schemata and Text (GIST) strategy toward students' reading comprehension.
\end{abstract}

Keywords: GIST strategy, Reading Comprehension

\section{INTRODUCTION}

English as an international language has four language skills, there are; listening, speaking, reading and writing. Among the four language skills in English, reading is one of the most important ability to be taught because by reading, students can get more information and experience as the input of the teaching learning process since it is a source of information. Students can get the new information and knowledge based on what they have learnt, it can be said that reading has an important role in students' achievement. Mc.Namara 
(2007: 3) state "Reading is an extraordinary achievement when one considers the number of levels and components that must be mastered". Reading is skill needed by students to increase students' knowledge and other English skills and components. The components of reading include oral and written language.

The goal of reading is comprehension. According to Woolley (2011: 15) Reading comprehension is the process of making meaning from text. It means that reading comprehension is the ability to take information from written text and do something with it in a way that demonstrates knowledge or understanding of that information. Reading comprehension is a complex activity for the reader to understand and comprehend the meaning of words.

To teaching reading comprehension, teacher must have a comfortable strategy of teaching to help the students learn English and grow the teaching learning process to be more active and creative. One of the teaching strategies that is considered useful is Generating Interaction between Schemata and Text (GIST) strategy, proposed by Cunningham in Bouchard (2005: 40). This strategy provides an opportunity for students to identify important vocabulary and synthesize important pieces of information into summary statement to show the gist of the reading. By using this strategy, the students expected to be easier to comprehend the reading text especially in narrative text.

Based on the background of the study above, the identification of the research is Generating Interaction between Schemata and Text (GIST) strategy can be applied in teaching reading comprehension. This strategy useful and involves students' prior knowledge, synthesizing and generalizing cognitive operation.

The research was limited the discussion of study about, "The Effect of Generating Interaction between Schemata and Text (GIST) strategy towards students' reading comprehension." The objective of the research had the objective of the study was to know whether there is any significant effect of Generating Interaction between Schemata and Text (GIST) strategy towards students' reading comprehension.”

\section{REVIEW OF RELATED LITERATURE}

Grabe (2009: 4) state that reading is something many of us take for granted. By reading, the reader can appear a little effort and little planning, because the reader constructs 
the meaning of the text. The purpose of reading is comprehension. Comprehension is the process of understanding interpretation of the words. The readers know and understand the meaning of the words. According to Snow (2002:11) reading comprehension is as the process of simultaneously extracting and constructing meaning through interaction and involvement with written language. It means reading comprehension is process of interpreting, constructing meaning and understanding the meaning of the text.

Teaching strategy is very important for developing and increasing students' reading comprehension. Therefore, it is essential that the teachers use and apply appropriate strategy in the class. The teacher can use GIST (Generating Interaction between Schemata and Text) strategy in teaching reading comprehension. According Cunningham in Herrell (2012: 250) GIST is a strategy for supporting comprehension of informational text. GIST is especially helpful when students are required to read long texts that contain a significant amount of new information and assists the student to comprehend the text.

The procedures of GIST strategy according Bouchard (2005: 40) are as follow:

1) Prepare a transparency of a section of text or designates a portion of text to be read. This usually includes text that may be a challenge for the students.

2) Typically, in a class of all native English speakers, you and students read the section silently. For students, it is more effective if you read the passage aloud while they follow along.

3) As a class, decide upon the "most important" words or concepts that are essential to understanding that portion of the text. (The number of concepts and words may vary depending upon the length of the text.) Teacher can underline or highlight these on the overhead. (It is helpful for students to have a copy of the text so they can underline also.) Teacher can also ask students to write the words and concepts.

4) Using as many of the "most important words and concepts" as possible, write a summary statement consisting of one or two sentences together with students.

5) Each student then writes the completed summary statement.

6) Repeat the procedure using subsequent sections of the text. 
7) Finally, students use the summary statements that have already been generated as a comprehensive summary for the entire text. These can be grouped together to form a summary paragraph.

Moreover, GIST strategy can be applied in cooperative groups. Working in cooperative group can be applied if the students already familiar with the process. The steps follow here by Bouchard (2005: 41):

1) Assign a section of text for students to read.

2) Form groups and assign a group leader.

3) Students read the text silently (or a group member can read it aloud).

4) The group collaboratively identifies important vocabulary and concepts based on setting, event, character and character's problem.

5) The group develops the summary statement identifying the gist of the reading.

6) Each member of the group writes the summary statement on a piece of paper.

7) The group reads the next portion of text and repeats the process.

8) Move from group to group observing and providing support when needed.

9) Each group presents its summary statement(s).

10) Discuss as a class and compare.

From the explanation above, it can be interpreted that GIST strategy is the summarizing strategy. The Effectiveness of summarizing process depends on the increasing of the students' learning and developing concept. Summarizing is needed for students to focus on the main concept of a text and to decide the important concept without omitting the concept of ideas. The ability to summarize the text has significant benefits for comprehending and obtaining the information. Teaching reading students by using GIST strategy helps them to synthesize information, summarizing thinking skill which includes identifying the concepts of the text and analyzing information of the text.

\section{RESEARCH METHODOLOGY}

The research used quantitative method by experimental design. Fraenkel (2006: 267) stated that experimental research is unique in two very important respects: It is the only type of research that directly attempts to influence a particular variable, and when properly applied, it is the best type for testing hypotheses about cause-and-effect relationships. 
Experimental research measures the effect of observed and controlled (independent) variable to another (dependent) variable, such as the effect of different methods of teaching to the students' achievement.

There are many kinds of experimental research design, such as pre-experimental design, true experimental, factorial design and quasi experimental (Ary et al, 2010:302). The research was conducted quasi experimental as the research design. The design was used because this method does not include the use of random assignment (Fraenkel, 2006: 277). In this research, two classes were taken as the sample classes: the experimental group and control group. The first group (experimental class) was treated by using Generating Interaction Schemata and Text (GIST) strategy and the second group (control class) was treated by using question guide strategy.

Reading comprehension test was distributed to the students as the instrument of the research. Before it was tested to the experimental class and control class as pretest, the researcher tested the instrument to the class besides the experimental and the control class to test the validity and reliability of the instrument. The indicators of reading comprehension competency was adapted from Brown theory (2003: 206) to assess the students reading comprehension; they are identifying meaning of word, identifying meaning of the text in explicit and implicit meaning, identifying main idea or topic, and identifying inference or message.

Related to the experimental design, the hypothesis testing in the research calculated by using the formula is as follow:

$$
\text { t-test } \quad=\frac{M x-M y}{\sqrt{\left\{\frac{\left.\sum x^{2}+\sum y^{2}\right)}{N x+N y-2}\right\}\left\{\frac{1}{N x}+\frac{1}{N y}\right\}}}
$$

where $\Sigma x^{2}=$ The total square of control class.

$\Sigma y^{2} \quad=$ The total square of experiment class.

$\mathrm{Mx}=$ The mean of control class.

My = The mean of experiment class.

$\mathrm{Nx}=$ The total number of control class.

Ny $\quad=$ The total number of experiment class. 
Furthermore, the researcher formulated the statistical hypothesis as follow:

Ho : Is accepted if $t_{\text {test }}<t_{\text {table. }}$. It means that Generating Interaction between Schemata and Text (GIST) Strategy does not give significant effect to student's reading comprehension in narrative text.

Ha : Is accepted if $t_{\text {test }}>t_{\text {table. }}$. It means that Generating Interaction between Schemata and Text (GIST) Strategy gives significant effect to student's reading comprehension in narrative text.

\section{FINDING AND DISCUSSION}

The data of this research was the score's pre-test and post-test. The researcher gave pre-test and post-test to all samples where the students were asked to answer the questions based on the instrument. In the pre-test, test was given to know ability both of classes (experiment and control) before given treatment. The post-test was given to evaluate the mean score both of sample classes after they got the treatment. After both classes did the test, the result would be evaluated. All the data were analyzed to find out the highest and lowest score of reading comprehension test, the mean score, standard deviation, and variance of each class.

Table 1. Score of Pre-test of Experimental and Control Class

\begin{tabular}{lcc} 
& \multicolumn{2}{c}{ Pre Test } \\
\cline { 2 - 3 } Item & Experimental Class & Control Class \\
\hline Minimum Score & 45 & 40 \\
Maximum Score & 80 & 75 \\
Mean & 62.30 & 57.43 \\
Standard Deviation & 6.62 & 7.80 \\
Variance & 43.88 & 60.84 \\
$\mathrm{~N}$ & 37 & 35 \\
\hline
\end{tabular}

Based on the result, the value of t-test was 7.63 with $d k=n_{1}+n_{2}-2(37+35-2)$ so, $\mathrm{dk}=70$ found $\mathrm{t}_{\text {table }}=1.994$. Based on hypothesis criteria, if $\mathrm{t}_{\text {count }}<\mathrm{t}_{\text {table, }}$, it was $\mathrm{H}_{\mathrm{o}}$ will be accepted and if $\mathrm{t}_{\text {count }}>\mathrm{t}$ table, it was $\mathrm{H}_{\mathrm{a}}$ will be accepted. Whether, $\mathrm{H}_{\mathrm{o}}$ explain that GIST 
(Generating Interaction between Schemata and Text) strategy does not give significant effect towards students' reading comprehension and $\mathrm{H}_{\mathrm{a}}$ explain that GIST (Generating Interaction between Schemata and Text) strategy give significant effect towards students' reading comprehension. After comparing $t_{\text {count }}$ and $t_{\text {table, where }} t_{\text {count }}(7.63)>t_{\text {table }}(1.99)$, it means that $\mathrm{H}_{\mathrm{a}}$ was accepted and $\mathrm{H}_{\mathrm{o}}$ was rejected with statistical hypothesis that GIST (Generating Interaction between Schemata and Text) strategy gave significant effect to students' reading comprehension.

Table 2. Score of Post-test of Experimental and Control Class

\begin{tabular}{lcc}
\hline \multirow{2}{*}{ Item } & \multicolumn{2}{c}{ Post Test } \\
\cline { 2 - 3 } & Experimental Class & Control Class \\
\hline Minimum Score & 60 & 50 \\
Maximum Score & 95 & 85 \\
Mean & 77.84 & 66.71 \\
Standard Deviation & 7.32 & 7.66 \\
Variance & 53.53 & 58.74 \\
$\mathrm{~N}$ & 37 & 35 \\
\hline
\end{tabular}

Based on the finding of the research, it was found that the students who were taught by GIST (Generating Interaction between Schemata and Text) strategy have been effected the best parts of reading comprehension than the students who were taught by using Question Guide strategy because the students who were taught by using GIST (Generating Interaction between Schemata and Text) strategy can identify important vocabulary and synthesize important pieces of information into summary through GIST (Generating Interaction between Schemata and Text) strategy so that the student easily to comprehend the text. Based on the result of the pre-test before GIST (Generating Interaction between Schemata and Text) strategy was implemented, the ability of students to comprehend the text was lower than after using GIST (Generating Interaction between Schemata and Text) strategy was implemented.

After treatment and post-test was conducted, it was found that there were significant differences between GIST (Generating Interaction between Schemata and Text) strategy and 
Question Guide strategy where the post test score of class that taught by GIST (Generating Interaction between Schemata and Text) strategy was higher. The effect of the students who taught by using GIST (Generating Interaction between Schemata and Text) strategy is higher than the effect of students who taught without using Question Guide strategy.

The result of the data analysis showed that the strategy of using GIST (Generating Interaction between Schemata and Text) strategy in students' reading comprehension seemed to be applicable for junior high students. The strategy encouraged the students to be more active and motivated in teaching reading. It was proven that there was significant effect of GIST (Generating Interaction between Schemata and Text) strategy towards students' reading comprehension.

In this research, the researcher used GIST (Generating Interaction between Schemata and Text) strategy to give the effect students' reading comprehension that means that the findings are only representative to that school. The researcher hopes that more research will be done by the others to prove this strategy in teaching and learning English.

\section{CONCLUSION AND SUGGESTION}

Based on the result of the discussion from the data analysis presented, it can be concluded that the students who were taught by using GIST (Generating Interaction between Schemata and Text) strategy got better achievement than the students who were taught by using Question Guide strategy. GIST (Generating Interaction between Schemata and Text) strategy can increase students' achievement in reading comprehension especially in narrative text at SMPN 41 Batam. It can be proven by the value of $t$ count (7.63) was bigger than the value of $\mathrm{t}_{\text {table }}(1.99)$, the alternative hypothesis was accepted and the null hypothesis was rejected. It means GIST (Generating Interaction between Schemata and Text) strategy is bigger in giving significant effect toward students' reading comprehension in narrative text.

Based on the conclusion above, this research has implication for the student and the teacher in the class. For the students, this strategy was easily for them to find out the main idea in each paragraph by identifying important vocabulary and concepts based on setting, event, character and character's problem. For teachers, they can choose one of students to read aloud the text after that teacher asks to identify important vocabulary and concepts 
based on setting, event, character and character's problem. Next, teacher asks students to develop summary statement and discussed summary together.

Based on the implication above, the researcher proposes some suggestions. Those are expected to be useful for further research, English teacher, students, readers, and for whom that may be concerned with English education and particularly in teaching reading comprehension. For the next researcher who wants to apply this strategy, it is hoped that they are able to support as one of the reference for the further research to solve the students' reading comprehension problem or any problems in another English skills. One thing that should be noticed by the researcher in applying GIST (Generating Interaction between Schemata and Text) strategy is the researcher has to control the students' work. Then for the teacher who want to apply this strategy, it is hoped it could inspire them to use appropriate strategy in teaching English especially in improving students reading comprehension and build a new atmosphere in English class since it was not easy for students to easy understand the foreign language like English. In teaching and learning process, teacher is as a guide who asks students to read the text and identify important vocabulary and concepts based on setting, event, character and character's problem and then develop summary statement of the text.

\section{BIBLIOGRAPHY}

Arikunto, Suharsimi. 2006. Prosedure Penelitian Suatu Pendekatan Praktik Edisi Revisi VI. Jakarta: RinekaCipta.Ary, Donald, Azhar Razavieh and Lucy Cheser Jacobs. 2002. Introduction to Research in Education: New York.

Ary, Donald, Azhar Razavieh and Lucy Cheser Jacobs. 2002. Introduction to Research in Education: New York.

Bouchard, Margaret. 2005. Comprehension Strategies for English Language Learners.USA: Scholastic Inc.

Brown, H. Douglas. 2003. Language Assessment Principles and Classroom Practices. San Fransisco: Longman.

Fraenkel, Jack R. and Norman E. Wallen. 2006. How to Design and Evaluate Research in Education. New York: McGraw-Hill.

Grabe, William. 2009. Reading in a Second Language Moving from Theory to Practice. New York: Cambridge University Press. 
Herrell, Adrienne L and Michael Jordan. 2012. Fifty Strategies for Teaching English Language Learners. America: Pearson Education.Mc.Namara, Danielle S. 2007. Reading Comprehension Strategies Theories, Interventions and Technologies. New York: Lawrence Erlbaum Associates.

Mc.Namara, Danielle S. 2007. Reading Comprehension Strategies Theories, Interventions and Technologies. New York: Lawrence Erlbaum Associates.

Snow, Catherine. 2002. Reading for Understanding: Toward a Research and Development Program in Reading Comprehension. Arlington: Rand.

Wooley, Gary. 2011. Reading Comprehension Assisting Children with Learning Difficulties. Australia: Springer. 